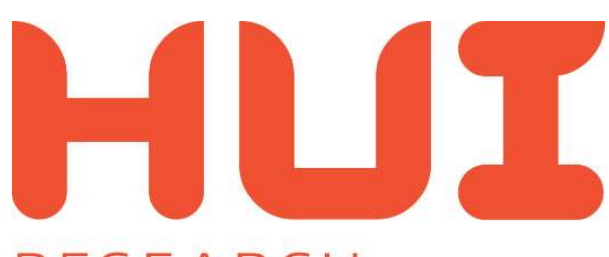

RESEARCH

\title{
Free to choose: Do voluntary audit reforms increase employment growth?
}

Asif M Huq

Sven-Olov Daunfeldt

Fredrik Hartwig

Niklas Rudholm

HUI Working Paper Series, number: 131

March, 2018

(C) Authors 


\title{
Free to choose: Do voluntary audit reforms increase employment growth?
}

\author{
Asif M Huq, Sven-Olov Daunfeldt, Fredrik Hartwig, Niklas Rudholm
}

\begin{abstract}
Many European countries have abolished mandatory audits for small firms to reduce the regulatory and administrative burden for these firms. However, we still lack knowledge on whether such legislative changes affect employment growth for those firms that become free to choose to have external audits. We investigate this question using a Swedish reform that made audits voluntary for small firms fulfilling certain requirements. The reform created an almost ideal natural experiment, which we use to evaluate the effects of voluntary audits on employment growth for small firms using a difference-in-difference estimator. We find that firms which fulfilled the requirements for voluntary auditing, compared to a control group of similar firms that did not, increased their employment growth rate by $0.39 \%$. This corresponds to 1,830 jobs being created in the year following the reform, suggesting that mandatory audits act as a growth barrier for small firms.
\end{abstract}

Keywords: Firm growth, small business economics, regulatory reform, mandatory audit JEL-codes: M42, M48, D22, J23 


\section{Introduction}

It has long been realized that small and medium-sized firms (SMEs) are important job contributors (Birch, 1979). SMEs have therefore attracted a lot of attention from policymakers, and several policies have been introduced to induce, sustain, and improve the operation and growth of SMEs (Nightingale \& Coad, 2014).

However, most SMEs do not grow at all or grow very slowly (Hodges \& Østbye, 2010), despite having the financial resources to do so (Bornhäll, et al., 2015). Many of these SMEs might have chosen to increase their number of employees if the institutional conditions for firm growth had been more favorable (Davis \& Henrekson, 1999). Growth of small firms is, in general, more sensitive to regulations than the growth of large firms (Demirguc-Kunt \& Maksimovic, 1998; Beck et al., 2005), suggesting that the regulatory burden of SMEs might act as one such growth barrier. One policy reform that has been widely used in Europe to reduce the regulatory burden of SMEs is the abolition of mandatory audit requirements (Federation of European Accountants, 2016).

Auditing is often considered as burdensome and inefficient, suggesting that it might prevent SMEs from increasing their number of employees (Chung \& Narasimhan, 2001; Kamarudin, et al., 2012). On the other hand, external audits have also been claimed to be positive for SMEs (Collis, et al., 2004; Minnis, 2011; Dedman, et al., 2014), and even have a positive influence on the performance of SMEs (Barbera \& Hasso, 2013; Carey, 2015). However, most SMEs opt out of audit when given a choice (Dedman, et al., 2014; Ojala, et al., 2016), indicating that the perceived costs of auditing tend to outweigh the benefits for the firm.

Legislative changes that decrease the regulatory burden on small firms are often justified on the grounds that regulation favors large firms, but decreases small firms' growth aspirations (Nooteboom, 1993; Henrekson \& Johansson, 1999; Klapper, et al., 2006). However, empirical studies on how accounting regulations affect firm growth are rare (Akisik, 2013). Previous studies have instead tried to identify what determines the demand for voluntary audits (e.g., Seow, 2001; Rennie, et al., 2003; Collis, et al., 2004; Collis, 2010; Lennox \& Pittman, 2011; Collis, 2012; Dedman \& Kausar, 2012; Niemi, et al., 2012; Dedman, et al., 2014; Ojala, et al., 2016), the potential benefits of auditing, (Allee \& Yohn, 2009; Minnis, 2011) or the costs accociated with mandatory audits (Kamarudin, et al., 2012). These studies are often restricted to very small firms (Niemi, et al., 2012; Ojala, et al., 2016), and based on survey data with 
samples that are small and non-representative (Chung \& Narasimhan, 2001; Rennie, et al., 2003; Collis, 2012).

We take a different approach by investigating the effect of a Swedish audit reform in 2010 on the employment growth of small firms. The reform reduced the regulatory and administrative burden on Swedish micro firms, and was designed in a way that created a natural experiment with clearly defined treatment and control groups. Except for differences in their status, regarding mandatory or voluntary audits, firms in the treatment and control group shared many characteristics. The details of the reform were not discussed, neither in parliament nor in the media, for any long period before the legislation was implemented. It is thus unlikely that the new regulation was anticipated by the firms, which means that the reform can be considered as an exogenous event for the treated firms. Such natural experiments constitute one of the best ways to identify causal effects (Pischke \& Angrist, 2009), although they rarely have been used to investigate the effects of financial reporting regulation (Leuz and Wysocki, 2016).

The treatment group consists of all firms that after the reform satisfied the criteria for voluntary audits, while our control group consists of all firms with fewer than 20 employees that still were subject to mandatory audits. As far as we know, our study is the first to use a natural experiment to investigate how a change in audit regulations affects employment growth for small firms. Note that our study also covers all limited liability firms in Sweden active during the whole study period (2009-2013), which means that we have no selection bias, as long as inference is drawn for surviving firms. Surviving firms in the control group can thus be used to estimate the counterfactual outcome, i.e., how firms in the treatment group would have developed in the absence of the audit reform.

We find that the number of employees increased, on average, by $0.39 \%$ in the treated firms, compared to firms in the control group. This implies that 1,830 new jobs were created in the year following the reform. We also find substantial industry heterogeneity in how the reform affected employment growth, suggesting that there are significant industry differences in how audit regulations affect the growth aspirations of a firm and their perceived costs of auditing (Anderson \& Zéghal, 1994; Gonthier-Besacier \& Schatt, 2007; Hassan \& Naser, 2013; Kikhia, 2015). Our findings thus indicate that mandatory audits act as a growth barrier, and provide support for institutional reforms that make audits voluntary for small firms.

The remainder of this paper is structured as follows: Section 2 discusses the Swedish audit reform and presents our hypotheses. Section 3 presents the data, the empirical model and our estimation results. Finally, our results are summarized and discussed in Section 4. 


\section{The Swedish audit reform and hypotheses to be tested}

The EU Fourth Company Law Directive (78/660/EEC) provides the EU member states with the option to exempt SMEs from mandatory audits (European Economic Community, 1978), and most countries within the EU also use this option to exempt SMEs from auditing. Sweden was for a long time a rare exception, with audits being a requirement for all Swedish limited firms, even the smallest ones. The Swedish legislation can be dated back to 1895 when the Companies Act was re-written, making it mandatory for all limited firms to appoint independent auditors (Öhman \& Wallerstedt, 2012). ${ }^{1}$

In 2006, a center-right government was elected in Sweden. The newly elected government submitted the Bill, "A Voluntary Audit" (Prop. 2009/10:204), to the Swedish parliament on April 14, 2010, proposing that small firms should be allowed to choose whether they would have an auditor or not. The reform was justified on the grounds that the government wanted to reduce the regulatory burden on small firms, which complied with the European Commission's plan ${ }^{2}$ to reduce SME's administrative burden by $25 \%$. The bill was passed by the Swedish Parliament on June 21, 2010 (SFS 2010:834), and the new legislation allowed firms not exceeding certain thresholds to be exempted from statuary audits. The change applied to fiscal years beginning on, or after, November 1, 2010 (SFS 2010:834), and the reform was expected to exempt approximately $72 \%$ of all Swedish limited firms from mandatory audits (Svanström \& Sundgren, 2012).

Formally, the Swedish Companies Act (Aktiebolagslagen, 2005:551) Chapter $9 \S 1$ still stipulates that - as a starting point - all Swedish limited firms are required to have an auditor. ${ }^{3}$ The Articles of Association of a privately owned, limited firm may, however, from November 1,2010 , specify that the firm does not need to have an auditor, given that at least two of the following three conditions are met: ${ }^{4}$

\footnotetext{
${ }^{1}$ Voluntary audits can be dated back to the 1650 s in Sweden, and official, but nevertheless voluntary, audits were also mentioned in the Companies Act of 1848 .

${ }^{2}$ As per the EU Fourth Company Law Directive (78/660/EEC). Reports from the European Commission highlighted the importance of SMEs for the European economy and called for a more business-friendly environment for SMEs, including micro firms, so that they could become more competitive in the global economy. ${ }^{3}$ Note that according to the Swedish Companies Act (Aktiebolagslagen 2005:551) Chapter $9 \S 12$, only authorized public accountants, or approved public accountants, , are allowed to conduct statuary audits. In larger and/or listed firms, at least one auditor must be an approved public accountant. Regulations concerning authorized public accountants and approved public accountants can be found in the Swedish Public Accountants Act (Revisorslag 2001:883).

${ }^{4}$ This also applies to the parent company of a group (even though the threshold levels in the parent company are not exceeded), if the group meets more than one of the specified conditions. All intercompany claims and transactions should, however, first be eliminated.
} 
i. The average number of employees for the previous two consecutive fiscal years amounts to no more than 3 .

ii. Reported total assets for the previous two consecutive fiscal years amounts to no more than 1.5 million SEK.

iii. Reported net sales for the previous two consecutive fiscal years amounts to no more than 3 million SEK.

The threshold levels mean that only micro firms have the option to opt out of the mandatory audit in Sweden. In other European countries, with Finland and Malta as the only exceptions, the thresholds for mandatory audits are much higher (see Table 1) and apply to SMEs rather than just micro firms.

[Table 1 about here]

The total audit process can be highly complex and is something that requires a large amount of time, depending on the size and characteristics of the client. It thus requires a substantial amount of resources, both for the auditor and the firm being audited. The voluntary audit reform has been estimated to save firms in the treatment group 5.8 billion $\mathrm{SEK}^{5}$ annually (SOU 2008:32), and this figure does not include cost savings due to reductions in the amount of work in the treated firms during the audit process. Note that firms that still choose to audit after the change in regulation will also benefit from having the possibility of voluntary audits as it increases the firm's range of measures to reduce costs in times of economic difficulty. As such, all firms in the treatment group benefit, either directly or indirectly, from the reduction in regulatory burden that the reform creates, making resources available for firms in the treatment group to increase employment relative to those in the control group. The first hypothesis that we want to test is therefore:

H1: Firms having the option of voluntary audit will have higher employment growth than similar firms not having this option.

Previous studies have found significant heterogeneity in auditing costs for different industries (Anderson \& Zéghal, 1994; Gonthier-Besacier \& Schatt, 2007; Hassan \& Naser, 2013; Kikhia, 2015). Firms within some industries have reported high auditing costs, e.g., IT-industries (Gonthier-Besacier \& Schatt, 2007) and manufacturing industries (Kikhia, 2015), even though Hassan \& Naser (2013) found that manufacturing companies pay significantly lower audit fees compared to service and retail firms. Anderson \& Zéghal (1994) also found that the

\footnotetext{
${ }^{5}$ Approximately 643 million USD, exchange rate 2017-12-11.
} 
transportation, communication and utilities industry pay significantly lower audit fees compared to other industries, but they did not find any significant difference between mining and manufacturing industries when compared separately to other industries. This indicates that the direct and indirect benefits of belonging to the treatment group will differ among industries.

We have not found any Swedish studies of how the costs of auditing differ across industries and our dataset does not contain any information regarding auditing costs specifically. However, given that previous studies have found that such differences exist in other countries, it seems unlikely that they would not do so also in Sweden. We thus expect that the reduction in regulatory and administrative burden from voluntary audits differs among industries, and that the impact of the audit reform of 2010 on employment growth consequently differs among industries. Our second hypothesis is therefore:

H2: Differences in the reduction in regulatory and administrative burden across industries will cause industry heterogeneity in the effect of the reform on employment growth.

\section{Empirical Study}

\subsection{Data}

The data are collected from the Retriever database, which contains corporate information of all registered limited liability firms in Sweden. In our sample, we include all firms that were registered before January 2009, and still active in December 2013. This means that our study is based on surviving firms, and that inference cannot be drawn for start-ups and firms that exited during the study period.

Our treatment group consists of all firms that were not subject to mandatory audit after the reform, while our control group consists of all firms with fewer than 20 employees that did not satisfy the criteria for voluntary audits. ${ }^{6} \mathrm{We}$ restrict our control group to firms with fewer than 20 employees, because growth patterns and growth ambitions differ substantially between small and large firms (Nightingale \& Coad, 2014). ${ }^{7}$

\footnotetext{
${ }^{6}$ Results (available upon request) are similar when the firm size cut-offs are 10, 15, 25 or 30 employees.

${ }^{7}$ Riksrevisionen (2017) instead compares the outcome for firms that chose not to audit with firms that chose to continue auditing after the reform. Their results indicate that firms that chose to audit had higher growth than similar firms which did not conduct any audits. However, this result is likely due to the firms choosing to audit having higher growth ambitions than their non-audited counterparts. Previous studies (Dedman et al., 2014; Ojala et al., 2016) found that choosing voluntary audit is a strong indication of the firm having growth ambitions, and external financiers also often provide investment capital at lower rates for audited firms (Huq et al., 2018). As such, these firms would likely have grown faster even in the absence of the voluntary audit reform.
} 
Our study period runs from 2009 to 2011, with the control period being 2009, the intervention period being 2011, and with 2010 excluded due to it being the year the reform was introduced. ${ }^{8}$ We use relative growth in the number of employees as our dependent variable, where the relative employment growth rate of firm $i$ during year $t$ is calculated as follows:

$$
G_{i, t}=\text { Ln employees }_{i, t}-\text { Ln employees }_{i, t-1}
$$

Logarithmic difference is one of the most frequently used firm growth measures (Coad, 2009; Coad, et al., 2014), with the convenient property of being symmetric for positive and negative growth rates (Törnqvist, et al., 1985).

\subsection{Empirical method}

To test whether firms in the treatment group grow faster than firms in the control group, due to their option not to conduct any audits, we estimate the following difference-in-difference model:

$$
G_{i, t}=\alpha_{i}+\beta_{1} t p_{t}+\beta_{2} \operatorname{tg}_{i, t}+\beta_{3}\left(t_{t} \times \operatorname{tg}_{i, t}\right)+\varepsilon_{i, t}
$$

where $G_{i, t}$ is relative employment growth in firm $i$ in year $t, t p_{t}$ is an indicator variable equal to one in the treatment period, zero otherwise; and $\operatorname{tg}_{i, t}$ is an indicator variable equal to one for firms belonging to the treatment group, zero otherwise. The primary variable of interest in the model is the interaction term $\left(t p_{t} \times t g_{i, t}\right)$, which shows how firms in the treatment group and treatment years grow, compared to firms in the treatment group in the pre-treatment period, and firms in the control group over the whole study period. The estimated parameter $\beta_{3}$ will thus identify the effect of the Swedish audit reform on employment growth in the treated firms, all else being equal. ${ }^{9}$

In order to control for possible firm-level heterogeneity within the intervention and control groups, we also include firm-level fixed effects, $\alpha_{i}$, in the analysis. ${ }^{10}$ These fixed effects control for possible heterogeneity among firms in both the intervention and control groups in variables,

\footnotetext{
${ }^{8}$ To check the sensitivity of the model, two additional regressions were also run. As the reform was introduced in November 2010, the first considers the reform year 2010 as an intervention period, and the second considers 2010 as belonging to the control period. Additional regressions are also run using 2009 as the control period, and 20112013 as intervention period, excluding 2010 from the regressions. The results from all these additional estimations are similar to those reported in the paper and are available upon request.

${ }^{9}$ Note that the period under study coincides with the years after the financial crisis, starting with the default of Lehman Brothers in September 2008. However, for this to cause bias in the estimated reform effect, there needs to be a correlation both between the impact of the crisis and the fact of the firm being an intervention or control group firm specifically, as well as there being a second wave of the crisis in 2010 that affected the intervention or control group firms differently. We are not aware of any such events.

${ }^{10}$ Random effects models were also estimated with similar results, but since a Hausman test favored the use of fixed effects, the results from fixed effects models are presented in the paper. The results from the random effects estimations are available from the authors on request.
} 
such as growth ambitions, leadership skills, access to internal and external capital, firm location, year of firm entry, etc., given that they are (at least roughly) constant over the years under study. Descriptive statistics for the variables included in the estimation of eq. [1] are presented in Table 2.

\section{[Table 2 about here]}

As a robustness check, several additional regressions have been estimated. First, our results can be biased if there are omitted variables that are correlated with our interaction term measuring the reform effect (Studenmund, 2011, p. 171). ${ }^{11}$ Some early studies (Samuels, 1965; Singh \& Whittington, 1975) suggest large firms have higher average growth rates than small firms, while more recent studies (Audretsch, et al., 1999; Calvo, 2006; and Daunfeldt \& Elert, 2012) tend to find that small firms grow faster. As the reform is targeted specifically at micro firms, there will be differences in size between treated and untreated firms, even after introducing the 20 employees' cut-off. To control whether the size differences have an impact on our estimate of the reform effect, we also choose to include firm size as an explanatory variable in our estimated model.

We use two different variables to measure firm size, total sales and the value of total assets. Both variables are lagged one year to alleviate a potential endogeneity problem. If the reform was unexpected by the affected firms, there will be no correlation between the timing of the reform and firm size, and then the inclusion of the firm size variables will not change the size of the estimated reform effects in any significant way. If the reform was instead anticipated, and a correlation between size and the reform indicator exists, the inclusion of the size variables will reveal this as the estimated reform effect will change when the size variables are included.

Note that the estimated parameter $\beta_{3}$ shows the average reform effect over all Swedish industries. However, we know that it is likely that there are industry level differences in the reduction in the regulatory and administrative burden due to the reform (Section 2 above). The average reform effect over all industries could thus be driven by the outcome in a few industries, while firms in other industries are not significantly affected by the reform. We therefore also estimate eq. [1] separately for each of the 18 Swedish two-digit industry classification levels.

\footnotetext{
${ }^{11}$ Note that this requires the omitted variable to be correlated not only to being a treatmentgroup firm, but also to the timing of the reform.
} 


\subsection{Estimation results}

The results of the fixed-effects estimation of eq. [1] are presented in Table 3.

[Table 3 about here]

We find that the reform, on average, increased the employment growth rate in the treated firms by $0.39 \%$ (statistically significant at the 10\% level). In total, 469463 employees were employed in the treated firms the year before the reform was implemented. This implies that voluntary audits resulted in 1830 additional new jobs in Sweden during 2011. ${ }^{12}$

The results also show that the estimates of the reform effect do not change when firm size is included as an explanatory variable. This implies that the exclusion of firm size does not cause any omitted variable bias, and the results are also stable with regard to all robustness test regressions mentioned above.

The results when we make separate estimations for 18 Swedish two-digit industries are presented in Table 4, showing that voluntary audits had a positive effect on the employment growth rates for firms in six out of 18 industries. We thus find substantial industry level heterogeneity in how the reform affected firm growth.

[Table 4 about here]

One possible explanation for these industry differences is that there are significant differences among industries in the reduction of the regulatory and administrative burden due to the reform. Such differences can be due to industry differences in the cost of auditing, something that has been found in several previous studies (Anderson \& Zéghal, 1994; Gonthier-Besacier \& Schatt, 2007; Hassan \& Naser, 2013; Kikhia, 2015). The option not to audit will thus have a larger growth effect for those firms that are active in industries where auditing costs are high, thereby creating industry-level heterogeneity in the reform effect.

\section{Summary and discussion}

Most countries in the European Union have made auditing voluntary for small firms (Federation of European Accountants, 2016). One reason is that auditing increases the regulatory and administrative burden on small firms, and this burden might act as a growth barrier for small firms.

Sweden has, for a long time, been a rare exception in Europe, with auditing being mandatory for all limited liability firms. However, the Swedish government implemented a reform in 2010

$12469463 * 0,0039=1830$ new jobs. 
that made auditing voluntary for the smallest firms. The construction and timing of the reform made it an almost perfect natural experiment since the specifics of reform were only discussed a short period before the legislation was passed, which means that it is highly unlikely that the reform was anticipated by the treated firms. In addition, no part of the reform was under the control, of even influence, of the affected firms, making the reform an exogenous event for firms in the treatment group. This means that the reform can be used as a natural experiment to investigate the impact of voluntary auditing on the growth in the number of employees.

Our results show that the reform increased average employment growth rates in the treated firms by $0.39 \%$, which corresponds to 1,830 new jobs during 2011 , suggesting that mandatory audits act as a growth barrier for small firms.

The threshold level for mandatory audits is significantly lower in Sweden than in most other European countries, even after the reform. Most European countries require mandatory audits when the firm reaches 50 employees, while the same number in Sweden is only three employees. This suggests that more jobs could be created if the Swedish policymakers increased the threshold level for mandatory audits and made it more in line with the audit regulations in the rest of Europe.

Note that firms with certain characteristics and objectives ${ }^{13}$ will continue to hire external accountants and auditors, and may also choose to voluntary audit the firm, even if they are not subject to mandatory audits. However, a higher threshold will give more firms the possibility to adopt the auditing practices that they find most suitable to the firm, while auditors can improve their efficiency by concentrating on larger firms to a higher extent (see e.g., Chung \& Narasimhan, 2001). The benefit for society is that the option of not auditing removes a growth barrier for small firms. As most firms in the economy are small firms that do not grow, or grow only slowly, such reforms can have a significant aggregate impact on job growth.

A potential cost associated with the reform would be if firms no longer required to audit were to a larger extent involved in tax evasion or other forms of economic crime after the reform.

\footnotetext{
${ }^{13}$ According to numerous previous studies (e.g. Chow, 1982; Allee \& Yohn, 2009; Collis, 2010; Collis, 2012; Niemi, et al., 2012; Dedman, et al., 2014; Ojala, et al., 2016), among others, some typical characteristics of firms opting to voluntary audit have dispersed ownership, in other words, a large number of outside shareholders, relatively higher funding from bank or financial institutions compared to owners, the presence of a significant principal-agent relationship, and already depend heavily on auditors for non-audit services. The Director's perception of the value of information is also a prominent driver of voluntary audit (Collis, et al., 2004). Other objectives include, but are not limited to, access to outside capital, access to outside funds or capital at a lower cost, and better credit rating (Blackwell, et al., 1998; Allee \& Yohn, 2009; Lennox \& Pittman, 2011; Dedman \& Kausar, 2012). Lennox \& Pittman (2011) also argue that the option to choose audit allows companies to signal their type. Type refers to risk type of the borrowing company; a company that chooses to be audited voluntarily is more likely to be a low-risk borrower compared to a company which chooses not to be audited (Melumad \& Thoman, 1990).
} 
We do not have access to any data regarding the prevalence of tax evasion or economic crime at the firm or industry level. However, the Swedish National Council for Crime Prevention presents statistics on the number of yearly violations reported regarding the Revenue Offences Act (1971:69), and the Accounting Act (1999:1078). Regarding the Revenue Offences Act, the number of violations decreased from 21,572 in 2009 , to 17,808 in 2011 , while for the Accounting Act, the number of violations increased from 11,044 in 2009, to 12,260 in 2011. In 2016, the last year of data, 15,827 and 12,499 violations were reported for the Revenue Offences Act and the Accounting Act, respectively. As such, there does not seem to be any significant increases in economic crime, either in the short-term or long-term, following the voluntary audit reform. Also, it should be noted that the thresholds for voluntary audit are much higher in most of Europe compared to Sweden, indicating that European legislators have concluded that the benefits of voluntary audit outweigh the costs, including those associated with possible tax evasion and other forms of economic crime.

We also find that the effect of the reform on employment growth depends on the industry in which the firm is active. Industries for which we found a positive impact include agriculture, mining, information and communications, finance and insurance, professional services, training, and health care and social services. At present, we do not have access to any information on the auditing costs for firms at industry level. However, if such information could be collected, this would give the opportunity for several interesting avenues of future research. First, is it the case that the high cost of auditing industries in Sweden also coincides with those where we find a positive effect of the voluntary audit reform on firm employment growth? If so, this would strengthen our argument that the positive impact of audit reform on firm growth found in this paper is a causal effect of the reform. Second, how does the cost of auditing in different industries in Sweden compare to the estimates from other countries?

Our study has focused on the employment effects of mandatory audits, because reforms that reduce the regulatory burden on firms most often are implemented to create more jobs. However, such reforms might also influence firms in other ways. The additional resources that are made available due to the reform could, for example, be used for capital investments or for building up internal capital. We believe that this also constitutes an interesting area for further research. 


\section{Acknowledgments}

The authors would like to thank Ted Azarmi, Heilbronn University, Germany; participants at the European Accounting Associations 40 ${ }^{\text {th }}$ Annual Congress, Valencia, Spain, May 10-12, 2017, and the Conference of the Multinational Finance Society, Limassol, Cyprus, April 7-9, 2017; as well as participants of a seminar held at Dalarna University, January 27, 2017, for valuable comments and suggestions. 


\section{References}

Akisik, O., 2013. Accounting regulation, financial development, and economic growth. Emerging Markets Finance \& Trade, 49(1), pp. 33-67.

Allee, K. D. \& Yohn, T. L., 2009. The demand for financial statements in an unregulated environment: an examination of the production and use of financial statements by privately held small businesses. The Accounting Review, 84(1), pp. 1-25.

Anderson, T. \& Zéghal, D., 1994. The pricing of audit services: Further evidence from the Canadian market. Accounting and Business Research, 24(95), pp. 195-207.

Audretsch, D. B., Klomp, L., Santarelli, E. \& Thurik, R., 2004. Gibrat's Law: Are the services different?. Review of Industrial Organization, Volume 24, pp. 301-324.

Barbera, F. \& Hasso, T., 2013. Do we need to use an accountant? The sales growth and survival benefits to family SMEs. Family Business Review, 26(3), pp. 271-292.

Beck, T., Demirguc-Kunt, A. \& Maksivomic, V., 2005. Financial and legal constraints to growth: does firm size matter?. The Journal of Finance, 60(1), pp. 137-177.

Birch, D. L., 1979. The Job Generation Process. MIT Program on Neighborhood and Regional. Cambridge, MA: Massachusetts Institute of Technology.

Blackwell, D. W., Noland, T. R. \& Winters, D. B., 1998. The value of auditor assurance: evidence from loan pricing. Journal of Accounting Research, 36(1), pp. 57-70.

Bornhäll, A., Daunfeldt, S.-O. \& Rudholm, N., 2015. Sleeping gazelles: the unseen job creators?. Entrepreneurial Growth: Individual, Firm, and Region, pp. 161-185.

Calvo, J., 2006. Testing Gibrat's law for small, young and innovating firms. Small Business Economics, 26(2), pp. 117-123.

Cameron, A. C. \& Trivedi, P. K., 2005. Microeconometrics: methods and application. New York: Cambridge University Press.

Carey, P. J., 2015. External accountants' business advice and SME performance. Pacific Accounting Review, 27(2), pp. 166-188.

Chow, C. W., 1982. The demand for external auditing: size, debt and ownership influences. The Accounting Review, 57(2), pp. 272-291.

Chung, S. \& Narasimhan, R., 2001. Perceived value of mandatory audits of small companies. Managerial Auditing Journal, 16(3), pp. 120-123.

Coad, A., 2009. The Growth of Firms: A Survey of Theories and Empirical Evidence. s.1.:Edward Elgar: Cheltenham.

Coad, A. et al., 2014. High-growth firms: introduction to the special section. Industrial and Corporate Change, 23(1), pp. 91-112.

Collis, J., 2010. Audit exemption and the demand for voluntary audit: a comparative study of the UK and Denmark. International Journal of Auditing, Volume 14, pp. 211-231. 
Collis, J., 2012. Determinants of voluntary audit and voluntary full accounts in micro- and non-micro small companies in the UK. Accounting and Business Research, 42(4), pp. 441468.

Collis, J., Jarvis, R. \& Skerratt, L., 2004. The demand for the audit in small companies in the UK. Accounting and Business Research, 34(2), pp. 87-100.

Davis, S. J., \& Henrekson, M., 1999. Explaining national differences in the size and industry distribution employment. Small Business Economics, 12(1), 59-83.

Daunfeldt, S.-O. \& Elert, N., 2012. When is Gibrat's law a law?. Small Business Economics, 41(1), pp. 133-147.

Dedman, E. \& Kausar, A., 2012. The impact of voluntary audit on credit ratings: evidence from UK private firms. Accounting and Business Research, 42(4), pp. 397-418.

Dedman, E., Kausar, A. \& Lennox, C., 2014. The demand for audit in private firms: recent large-sample evidence from the UK. European Accounting Review, 23(1), pp. 1-23.

Demirguc-Kunt, A. \& Maksimovic, V., 1998. Law, finance, and firm growth. Journal of Finance, 53(6), pp. 2107-2137.

European Economic Community, 1978. [Online]

Available at: http://eur-lex.europa.eu/legal-content/EN/TXT/?uri=celex:31978L0660

[Accessed 25 November 2016].

Federation of European Accountants, 2016. Audit exemption thresholds in Europe. [Online] Available at:

http://www.fee.be/images/publications/auditing/1605 Audit exemption thresholds update.p $\underline{\mathrm{df}}$

[Accessed 25 November 2016].

Gonthier-Besacier, N. \& Schatt, A., 2007. Determinants of audit fees for French quoted firms. Managerial Auditing Journal, 22(2), pp. 139-160.

Greene, W. H., 2012. Econometric analysis. Seventh ed. Essex: Pearson Education Limited.

Hassan, Y. M. \& Naser, K., 2013. Determinants of Audit Fees: Evidence from an Emerging Economy. International Business Research, 6(8), pp. 13-25.

Henrekson, M. \& Johansson, D., 1999. Institutional effects on the evolution of the size distribution of Firms. Small Business Economics, Volume 12, pp. 11-23.

Hodges, H., \& Østbye, S., 2010. Is small firm gardening good for local economic growth? Applied Economics Letters, 17(8), pp. 809-813.

Huq, A., Hartwig, F. \& Rudholm, N., 2017. Do audited firms have lower cost of debt? Unpublished manuscript, Dalarna University.

Kamarudin, N., Abidin, Z. Z. \& Smith, M., 2012. Audit exemption among SMEs in Malaysia. Asian Review of Accounting, 20(2), pp. 152-162.

Kikhia, H. Y., 2015. Determinants of audit fees: evidence from Jordan. Accounting and Finance Research, 4(1), pp. 42-53. 
Klapper, L., Laeven, L. \& Rajan, R., 2006. Entry regulation as a barrier to entrepreneurship. Journal of Financial Economics, Volume 82, pp. 591-629.

Lennox, C. S. \& Pittman, J. A., 2011. Voluntary audits versus mandatory audits. The Accounting Review, 86(5), pp. 1655-1678.

Leuz, C. \& Wysocki, P.D., 2016. The economics of disclosure and financial reporting regulation: evidence and suggestions for future research, Journal of Accounting Research, 54(2), pp. 525-622.

Melumad, N. D. \& Thoman, L., 1990. On auditors and the courts in an adverse selection setting. Journal of Accounting Research, 28(1), pp. 71-120.

Minnis, M., 2011. The value of financial statement verification in debt financing: evidence from private U.S. firms. Journal of Accounting Research, 49(2), pp. 457-506.

Niemi, L., Kinnunen, J., Ojala, H. \& Troberg, P., 2012. Drivers of voluntary audit in Finland: to be or not to be audited?. Accounting and Business Research, 42(2), pp. 169-196.

Nightingale, P. \& Coad, A., 2014. Muppets and gazelles: political and methodological biases in entrepreneurship research. Industrial and Corporate Change, 23(1), pp. 113-143.

Nooteboom, B., 1993. Firms size effects on transaction costs. Small Business Economics, 5(3), pp. 283-295.

Ojala, H. et al., 2016. The demand for voluntary audit in micro-companies: evidence from Finland. International Journal of Auditing, Volume 20, pp. 267-277.

Pischke, J.-S. \& Angrist, J. D., 2009. Mostly Harmless Econometrics: An Empiricist's Companion. New Jersey: Princeton University Press.

Rennie, M., Senkow, D., Rennie, R. \& Wong, J., 2003. Deregulation of the private corporation audit in Canada: justification, lobbying, and outcomes. Research in Accounting Regulation, Volume 16, pp. 227-241.

Riksrevisionen, 2017. Avskaffandet av revisionsplikten för små aktiebolag - en reform som kostar mer än den smakar. RiR 2017:35 [Online] Available at:

https://www.riksrevisionen.se/sv/rapporter/Rapporter/EFF/2017/Avskaffandet-avrevisionsplikten-for-sma-aktiebolag--en-reform-som-kostar-mer-an-den-smakar/ [Accessed 4 March 2018].

Samuels, J. M., 1965. Size and the growth of firms. The Review of Economic Studies, 32(2), pp. 105-112.

Seow, J.-L., 2001. The demand for the UK small company audit an agency perspective. International Small Business Journal, 19(2), pp. 61-79.

Singh, A. \& Whittington, G., 1975. The size and growth of firms. The Review of Economic Studies, 42(1), pp. 15-26.

Studenmund, A. H., 2011. Using econometrics: a practical guide. 6th ed. Boston: Pearson Education, Inc..

Svanström, T. \& Sundgren, S., 2012. The demand for non-audit services and auditor-client relationships: evidence from Swedish small and medium-sized enterprises. International Journal of Auditing, Volume 16, pp. 54-78. 
Swedish Government, 2010. Regeringens proposition 2009/10:204, En frivillig revision (2009/10:204). [Online]

Available at:

http://www.regeringen.se/contentassets/b7693839f66f49079138ebad54098762/en-frivilligrevision-prop.-200910204

[Accessed 25 November 2016].

Swedish Government, 2010. Svensk författningssamling, SFS 2010:834. [Online]

Available at: https://www.notisum.se/rnp/sls/sfs/20100834.pdf

[Accessed 25 November 2016].

Sveriges Riksdag, 2005. Aktiebolagslag 2005:551. [Online]

Available at: http://www.riksdagen.se/sv/dokument-lagar/dokument/svensk-

forfattningssamling/aktiebolagslag-2005551 sfs-2005-551

[Accessed 25 November 2016].

Törnqvist, L., Vartia, P. \& Vartia, Y. O., 1985. How should relative changes be measured?. The American Statistician, 39(1), pp. 43-46.

Utredningen om revisorer och revision (Ju 2006:11), 2008. Avskaffande av revisionsplikten för små företag (SOU 2008:32). [Online]

Available at:

http://www.regeringen.se/49bb8e/contentassets/053cd8567e8e4f9eb722ba734d0186c8/avskaf fande-av-revisionsplikten-for-sma-foretag-hela-dokumentet-sou-200832

[Accessed 25 November 2016].

Öhman, P. \& Wallerstedt, E., 2012. Audit regulation and the development of the auditing profession: The case of Sweden. Accounting History, 17(2), pp. 241-257. 
Table 1: Threshold values (in euros) for mandatory audit in European countries as of May 2016 with corresponding increase from last ceiling.

\begin{tabular}{|c|c|c|c|c|c|c|}
\hline Country & $\underline{\text { Total assets }}$ & Increase & Net turnover & Increase & Employees & Increase \\
\hline Austria & $5,000,000$ & $3 \%$ & $10,000,000$ & $3 \%$ & 50 & - \\
\hline Belgium & $4,500,000$ & $23 \%$ & $9,000,000$ & $23 \%$ & 50 & - \\
\hline Bulgaria & $1,000,000$ & $33 \%$ & $2,000,000$ & $60 \%$ & 50 & - \\
\hline Croatia & $2,000,000$ & - & $4,000,000$ & - & 25 & - \\
\hline Cyprus & $3,400,000$ & - & $7,000,00$ & - & 50 & - \\
\hline Czech & $1,500,000$ & - & $3,000,000$ & - & 50 & - \\
\hline \multicolumn{7}{|l|}{ Republic } \\
\hline Denmark & $4,837,000$ & - & $9,674,000$ & - & 50 & - \\
\hline Estonia & $2,000,000$ & $100 \%$ & $4,000,00$ & $100 \%$ & 60 & $100 \%$ \\
\hline Finland & 100,000 & - & 200,000 & - & 3 & - \\
\hline France & $1,550,000$ & - & $3,100,000$ & - & 50 & - \\
\hline Germany & $6,000,000$ & $24 \%$ & $12,000,000$ & $24 \%$ & 50 & - \\
\hline Greece & $4,000,000$ & $60 \%$ & $8,000,000$ & $60 \%$ & 50 & - \\
\hline Hungary & - & - & 965,000 & $44 \%$ & 50 & - \\
\hline Iceland & $1,400,000$ & - & $2,800,000$ & - & 50 & - \\
\hline Ireland & $4,400,000$ & - & $8,800,000$ & - & 50 & - \\
\hline Italy16 & $4,400,000$ & - & $8,800,000$ & - & 50 & - \\
\hline Latvia & 800,000 & $100 \%$ & $1,600,000$ & $100 \%$ & 50 & $100 \%$ \\
\hline Lithuania & $1,800,000$ & - & $3,500,000$ & - & 50 & - \\
\hline Luxembourg & $4,400,000$ & - & $8,800,000$ & - & 50 & - \\
\hline Malta & 46,600 & - & 93,000 & - & 2 & - \\
\hline Netherlands & $6,000,000$ & $36 \%$ & $12,000,000$ & $36 \%$ & 50 & - \\
\hline Norway & $2,500,000$ & - & 625,000 & - & 10 & - \\
\hline Poland & $2,500,000$ & - & $5,000,000$ & - & 50 & - \\
\hline Portugal & $1,500,000$ & - & $3,000,000$ & - & 50 & - \\
\hline Romania & $3,650,000$ & - & $7,300,000$ & - & 50 & - \\
\hline Slovakia & $1,000,000$ & - & $2,000,000$ & - & 30 & - \\
\hline Slovenia & $4,000,000$ & $-9 \%$ & $8,000,000$ & $-9 \%$ & 50 & - \\
\hline Spain & $2,850,000$ & - & $5,700,000$ & - & 50 & - \\
\hline Sweden & 150,000 & - & 300,000 & - & 3 & - \\
\hline Switzerland & $18,203,000$ & - & $36,405,000$ & - & 250 & - \\
\hline $\begin{array}{l}\text { United } \\
\text { Kingdom }\end{array}$ & $6,541,000$ & $56 \%$ & $13,082,000$ & $57 \%$ & 50 & - \\
\hline
\end{tabular}


Table 2: Descriptive statistics.

\begin{tabular}{|c|c|c|c|}
\hline Variable & Mean & SD & Definition \\
\hline $\mathrm{G}_{\mathrm{i}, \mathrm{t}}$ & -0.00002 & 0.3002 & $\begin{array}{l}\text { Relative growth in percent in the number of } \\
\text { employees from year t- } 1 \text { to } t \text {. }\end{array}$ \\
\hline $\operatorname{tp}_{\mathrm{t}} \times \operatorname{tg}_{\mathrm{i}}$ & 0.4109 & 0.4920 & $\begin{array}{l}\text { Interaction between tp and tg. Measures the effect } \\
\text { of the reform on the treated firms. }\end{array}$ \\
\hline $\mathrm{tp}_{\mathrm{t}}$ & 0.4989 & 0.4999 & $\begin{array}{l}\text { An indicator variable equal to one during the } \\
\text { treatment period, zero otherwise. }\end{array}$ \\
\hline $\operatorname{tg}_{i, t}$ & 0.8637 & 0.3431 & $\begin{array}{l}\text { An indicator variable equal to one if the firm } \\
\text { belong to the treatment group, zero otherwise. }\end{array}$ \\
\hline Total sales ${ }_{\mathrm{i}, \mathrm{t}}(\mathrm{L})$ & $4.75 \mathrm{e}+10$ & $3.13 \mathrm{e}+13$ & $\begin{array}{l}\text { Total sales (in SEK) in year t-1. Used as a measure } \\
\text { of firm size. }\end{array}$ \\
\hline Total assets $\mathrm{i}_{\mathrm{i}, \mathrm{t}}(\mathrm{L})$ & $1.87 \mathrm{e}+11$ & $8.40 \mathrm{e}+13$ & $\begin{array}{l}\text { Total assets (in SEK) in year } \mathrm{t}-1 \text {. Used as a measure } \\
\text { of firm size. }\end{array}$ \\
\hline
\end{tabular}

Note: The descriptive statistics is based on the final sample used in the main regression analysis. 
Table 3: Estimation results, dependent variable $G_{i, t}$.

\begin{tabular}{|c|c|c|c|}
\hline Variables & Model 1 & Model 2 & Model 3 \\
\hline \multirow[t]{2}{*}{$\operatorname{tp}_{\mathrm{t}} \times \operatorname{tg}_{\mathrm{i}}$} & $0.0039 *$ & $0.0039 *$ & $0.0039 *$ \\
\hline & $(0.0022)$ & $(0.0022)$ & $(0.0022)$ \\
\hline \multirow[t]{2}{*}{$\mathrm{tp}_{\mathrm{t}}$} & -0.0020 & $-0.0020 *$ & -0.0020 \\
\hline & $(0.0015)$ & $(0.0015)$ & $(0.0015)$ \\
\hline \multirow[t]{2}{*}{$\operatorname{tg}_{i, t}$} & $-0.0229 * *$ & $-0.0232 * *$ & $-0.0229 * *$ \\
\hline & $(0.0050)$ & $(0.0050)$ & $(0.0050)$ \\
\hline \multirow[t]{2}{*}{ Total sales (L) } & & $-9.24 \mathrm{e}-11$ & \\
\hline & & $(6.33 e-11)$ & \\
\hline \multirow[t]{2}{*}{ Total assets (L) } & & & $1.69 \mathrm{e}-16^{*}$ \\
\hline & & & $(5.85 e-18)$ \\
\hline \multirow[t]{2}{*}{ Constant } & $0.0159 *$ & $0.0171^{*}$ & $0.0159 *$ \\
\hline & $(0.0035)$ & $(0.0036)$ & $(0.0035)$ \\
\hline Firm-specific f.e. & Yes & Yes & Yes \\
\hline Observations & 296,691 & 296,691 & 296,691 \\
\hline$\%$ change in $\mathrm{G}_{\mathrm{i}, \mathrm{t}}$ & $0.39 *$ & $0.39 *$ & $0.39 *$ \\
\hline
\end{tabular}

Note: The 19 employee firm-size cut-off is used in these estimations. ${ }^{*}$ statistically significant at the $5 \%$ level, * statistically significant at the $10 \%$ level.

Standard errors in parenthesis. (L) indicates variable lagged one year. 
Table 4: Estimation results, industry by industry, dependent variable $\mathrm{G}_{\mathrm{i}, \mathrm{t}}$

\begin{tabular}{|c|c|c|c|c|c|}
\hline Industry & $\operatorname{tp}_{\mathrm{t}} \times \operatorname{tg}_{\mathrm{i}}$ & $\operatorname{tp}_{\mathrm{t}}$ & $\operatorname{tg}_{i}$ & Observations. & $\begin{array}{c}\% \\
\text { change } \\
\text { in } \mathrm{G}_{\mathrm{i}, \mathrm{t}}\end{array}$ \\
\hline Agriculture & $\begin{array}{c}0.0460 * * \\
(0.0113)\end{array}$ & $\begin{array}{c}-0.0271 * * \\
(0.0076)\end{array}$ & $\begin{array}{c}-0.0348 * * \\
(0.0168)\end{array}$ & 8829 & $4.60^{* *}$ \\
\hline Mining & $\begin{array}{c}0.2668^{* *} \\
(0.0707)\end{array}$ & $\begin{array}{c}-0.0086 \\
(0.0192)\end{array}$ & $\begin{array}{l}-0.0064 \\
(0.0965)\end{array}$ & 421 & $26.68 * *$ \\
\hline Manufacturing & $\begin{array}{c}-0.0220 * * \\
(0.0070)\end{array}$ & $\begin{array}{c}0.0467 * * \\
(0.0039)\end{array}$ & $\begin{array}{c}-0.0259^{*} \\
(0.0150)\end{array}$ & 26812 & $-2.20 * *$ \\
\hline Electricity \& gas & $\begin{array}{l}-0.0487 \\
(0.0823)\end{array}$ & $\begin{array}{l}-0.0331 \\
(0.0300)\end{array}$ & $\begin{array}{c}0.2680 * * \\
(0.1304)\end{array}$ & 447 & -4.87 \\
\hline Water and waste management & $\begin{array}{l}-0.0569 \\
(0.0530)\end{array}$ & $\begin{array}{c}0.0319 \\
(0.0231)\end{array}$ & $\begin{array}{c}0.1284 \\
(0.1102)\end{array}$ & 671 & -5.69 \\
\hline Construction & $\begin{array}{c}0.0029 \\
(0.0064)\end{array}$ & $\begin{array}{c}0.0043 \\
(0.0042)\end{array}$ & $\begin{array}{l}-0.0183 \\
(0.0126)\end{array}$ & 38793 & 0.29 \\
\hline Retail and wholesale trade & $\begin{array}{c}-0.0011 \\
(0.0046)\end{array}$ & $\begin{array}{c}0.0001 \\
(0.0026)\end{array}$ & $\begin{array}{c}-0.0280^{* *} \\
(0.0097)\end{array}$ & 61534 & -0.11 \\
\hline Transportation & $\begin{array}{c}0.0051 \\
(0.0095)\end{array}$ & $\begin{array}{l}0.0165^{*} \\
(0.0060)\end{array}$ & $\begin{array}{c}-0.0580^{* *} \\
(0.0175)\end{array}$ & 16194 & 0.51 \\
\hline Hotels and restaurants & $\begin{array}{c}-0.0002 \\
(0.0144)\end{array}$ & $\begin{array}{c}-0.0183^{* *} \\
(0.0071)\end{array}$ & $\begin{array}{c}-0.0002 \\
(0.0262)\end{array}$ & 6668 & 0.02 \\
\hline Information and communication & $\begin{array}{c}0.0410 * * \\
(0.0104)\end{array}$ & $\begin{array}{c}-0.0420^{* *} \\
(0.0092)\end{array}$ & $\begin{array}{c}-0.0551^{* *} \\
(0.0253)\end{array}$ & 18142 & $4.10 * *$ \\
\hline Finance and insurance & $\begin{array}{c}0.0552 * * \\
(0.0198)\end{array}$ & $\begin{array}{c}-0.0567^{* *} \\
(0.0161)\end{array}$ & $\begin{array}{l}-0.0359 \\
(0.0439)\end{array}$ & 5266 & $5.52 * *$ \\
\hline Real estate & $\begin{array}{c}0.0135 \\
(0.0118)\end{array}$ & $\begin{array}{c}-0.0228 * * \\
(0.0089)\end{array}$ & $\begin{array}{l}-0.0435^{*} \\
(0.0280)\end{array}$ & 13185 & 1.35 \\
\hline Professional services & $\begin{array}{c}0.0224 * * \\
(0.0062)\end{array}$ & $\begin{array}{c}-0.0249 * * \\
(0.0057)\end{array}$ & $\begin{array}{c}-0.0341^{* *} \\
(0.0144)\end{array}$ & 59957 & $2.24 * *$ \\
\hline Renting real estate & $\begin{array}{c}0.0188 \\
(0.0144)\end{array}$ & $\begin{array}{c}-0.0009 \\
(0.0101)\end{array}$ & $\begin{array}{c}0.0392 \\
(0.0287)\end{array}$ & 9772 & 1.88 \\
\hline Training & $\begin{array}{c}0.0501 * * \\
(0.0204)\end{array}$ & $\begin{array}{c}-0.0587 * * \\
(0.0167)\end{array}$ & $\begin{array}{c}0.0295 \\
(0.0433)\end{array}$ & 4489 & $5.01 * *$ \\
\hline Health care and social services & $\begin{array}{l}0.0195^{*} \\
(0.0108)\end{array}$ & $\begin{array}{c}-0.0330^{* *} \\
(0.0091)\end{array}$ & $\begin{array}{l}-0.0287 \\
(0.0265)\end{array}$ & 10346 & $1.95 *$ \\
\hline Culture and recreation & $\begin{array}{c}0.0164 \\
(0.0180)\end{array}$ & $\begin{array}{l}-0.0221 \\
(0.0154)\end{array}$ & $\begin{array}{l}-0.0541 \\
(0.0437)\end{array}$ & 5593 & 1.64 \\
\hline Other Services & $\begin{array}{c}0.0231 \\
(0.0156)\end{array}$ & $\begin{array}{l}-0.0209 \\
(0.0121)\end{array}$ & $\begin{array}{c}0.0576 \\
(0.0404)\end{array}$ & 4583 & 2.31 \\
\hline
\end{tabular}

Note; The 19 employee firm-size cut-off is used in these estimations. ${ }^{* *}$ statistically significant at the 5\% level, ${ }^{*}$ statistically significant at the $10 \%$ level. Standard errors in parenthesis. (L) indicates variable lagged by one period. 